\title{
PENGARUH PHYSICAL EVIDENCE OBJEK WISATA PEMANDIAN AIR PANAS CIWALINI TERHADAP KEPUTUSAN BERKUNJUNG WISATAWAN \\ (Survei pada Wisatawan Nusantara Pemandian Air Panas Ciwalini-Ciwidey Kabupaten Bandung)
}

\author{
Rizka Putri Ananda \\ Eeng Ahman \\ Oce Riwanudin \\ Manajemen Pemasaran Pariwisata FPIPS UPI
}

\begin{abstract}
Kabupaten Bandung is one of regions that has a lot of potential tourism object since it has many alternative destination for tourists to visit.One of the strenght of Bandung tourism are the enormous number of eco tourism objec ts that can be managed as best tourism area.Pemandian Air Panas Ciwalini is one out of 28 ecotourism destination that lays in Kabupaten Bandung.Every year the amount of visitors who visit pemandian Air Panas Ciwalini are fluctuated, which is seems to be decreased in the last two years.Based on the data, a research of effort on increasing the amount of visitor through management of physical evidence inside the site had been conducted.The aims of this research is to gain the result of examination about (1) Physical evidence which consist of facililty exterior, facility interior and other tangibles in the tourism object Pemandian Air Panas Ciwalini. (2) Visiting decisions which consist of choosing the tourism product, choosing the brand, choosing the travel agent, amount of visiting, and decision of visiting time of the tourist to Pemandian Air Panas Ciwalini. (3) The effect of physical evidence to the decision of the tourist on visiting Pemandian Air Panas Ciwalini.The object of this research is to acknowlegde the physical evidence which consist of facility exterior, facility interior and other tangibles on the the local tourist's decisions to visit Pemandian Air Panas Ciwalini.The kind of research is descriptive and verivicative which use explanatory survey method.Population in this research was the domestic tourist from accros the country in Pemandian Air Panas Ciwalini.100 people had been taken to be the samples of the research which is using simple random sampling.Data analysis technique that is used in this research is Path Analysis MethodThe result on hipothesis examination showed that the physical evidence which consist sub variable such; exterior facilities, interior facilities and other tangibles, gives effects on visiting decisions to Pemandian Air Panas Ciwalini Interior facilities deliver the highest effects on taking the visit decision, whereas eksterior facilities give the lowest effects.
\end{abstract}

Key Words :Physical evidence, decision on visiting and eco tourism.

\section{PENDAHULUAN}

\subsection{Latar Belakang}

Pengembangan kepariwisataan Jawa

Barat tidak terlepas dari munculnya berbagai isu strategis pembangunan. Ketimpangan pembangunan poros utara-tengah-selatan, penyediaan lapangan kerja, pengurangan kemiskinan, optimalisasi kinerja pemerintah daerah, lemahnya sinergitas antar unit kerja, pelibatan masyarakat, maupun pengembangan sumber daya manusia merupakan beberapa isu khusus yang juga berpengaruh terhadap perkembangan kepariwisataan Provinsi Jawa Barat (Bappeda Provinsi Jawa Barat,2005)
Kebijakan, strategi, serta program pembangunan seperti yang tertuang dalam Perda No. 1 Tahun 2004 tentang Rencana Strategis Pemerintah Provinsi Jawa Barat, mengisyaratkan bahwa pengembangan dan pembangunan sektor pariwisata memegang peranan penting dalam pengembangan wilayah. Melalui pengembangan kawasankawasan andalan yang terdapat di Provinsi Jawa Barat, secara internal pengembangan sektor kepariwisataan diharapkan dapat memberikan kesejahteraan bagi masyarakat dan secara eksternal diharapkan mampu menjadi sektor utama yang memberikan dampak menyebar pada wilayah sekitarnya demi menciptakan pemerataan wilayah. 
Jawa Barat memiliki potensi pariwisata yang begitu beragam, baik dari sisi produk wisata maupun pasar wisatawan, dengan alam dan budaya yang dimiliki, Jawa Barat menawarkan berbagai daya tarik wisata. Potensi pasar wisatawan Jawa Barat juga tidak kalah besarnya. Kedekatan Jawa Barat dengan provinsi-provinsi berpenduduk banyak dan sudah berkembang menjadikan Jawa Barat kaya akan sumber pasar wisatawan yang tentunya dapat dijadikan objek kunjungan baik oleh wisatawan nusantara maupun wisatawan mancanegara. Adapun data jumlah kunjungan wisnus dan wisman, dapat dilihat pada Tabel 1.1 sebagai berikut:

TABEL 1.1

DATA KUNJUNGAN WISATAWAN KE JAWA BARAT TAHUN 2007-2011

\begin{tabular}{|c|c|c|c|c|}
\hline \multirow[b]{2}{*}{ Tahun } & \multirow{2}{*}{$\begin{array}{l}\text { Wisatawan } \\
\text { Nusantara }\end{array}$} & \multirow{2}{*}{$\begin{array}{c}\text { Wisatawan } \\
\text { Asing }\end{array}$} & \multicolumn{2}{|c|}{ Pertumbuhan (\%) } \\
\hline & & & $\begin{array}{l}\text { Wisatawan } \\
\text { Nusantara }\end{array}$ & $\begin{array}{c}\text { Wisatawan } \\
\text { Asing }\end{array}$ \\
\hline 2007 & 23.859 .547 & 227.068 & & \\
\hline 2008 & 23.782 .802 & 338.959 & $-0,3$ & 49,3 \\
\hline 2009 & 24.075 .027 & 254.551 & 1,2 & $-24,9$ \\
\hline 2010 & 25.066 .687 & 205.033 & 4,1 & $-19,5$ \\
\hline 2011 & 25.781 .420 & 215.347 & 2,8 & 5,0 \\
\hline
\end{tabular}

Sumber : Dinas Pariwisata dan Kebudayaan Provinsi Jawa Barat, 2011

Berdasarkan Tabel 1.1 di atas pertumbuhan jumlah wisatawan yang berkunjung ke Jawa Barat baik wisatawan nusantara maupun mancanegara cenderung meningkat, namun dilihat trend pertumbuhannya wisatawan nusantara relatif stabil dan berbanding terbalik dengan pertumbuhan jumlah wistawan mancanegara yang seringkali fluktuatif bahkan tahun 2010 terjadi penurunan pertumbuhan. Pada tahun 2007 jumlah wisatawan nusantara tercatat sebanyak 23.859.547 orang dan sampai akhir tahun 2011 tercatat sebanyak 25.781.4207 orang, dan jumlah wisatawan mancanegarapun

di tahun 2011 kembali terjadi peningkatan sebesar 5,0\%.

Meningkatnya kecenderungan masyarakat untuk melakukan perjalanan wisata tentunya dapat berdampak positif bagi perkembangan sektor pariwisata di Jawa Barat. Melalui pengembangan kawasan-kawasan andalan yang terdapat di Provinsi Jawa Barat, secara internal pengembangan sektor kepariwisataan diharapkan dapat memberikan kesejahteraan bagi masyarakat, dan secara eksternal diharapkan mampu menjadi sektor utama yang memberikan dampak menyebar pada wilayah sekitarnya demi menciptakan pemerataan wilayah.

Kabupaten Bandung merupakan salah satu kawasan wisata yang memiliki potensi wisata yang cukup besar karena terdapat banyak jenis wisata yang dapat menjadi alternatif pilihan wisatawan untuk berkunjung. Salah satu kekuatan pariwisata Kabupaten Bandung adalah banyaknya jenis wisata alam yang dapat dijadikan sebagai kawasan wisata unggulan. Sebagai gambaran Tabel 1.2 menunjukkan jumlah wisatawan yang berkunjung ke Kabupaten Bandung. 
TABEL 1.2

DATA KUNJUNGAN WISATAWAN KE KABUPATEN BANDUNG TAHUN 2007-2011

\begin{tabular}{|c|c|c|c|c|}
\hline \multirow{2}{*}{ Tahun } & \multirow{2}{*}{$\begin{array}{c}\text { Wisatawan } \\
\text { Nusantara }\end{array}$} & $\begin{array}{c}\text { Wisatawan } \\
\text { Asing }\end{array}$ & \multicolumn{2}{|c|}{$\begin{array}{c}\text { Pertumbuhan } \\
(\%)\end{array}$} \\
\cline { 4 - 5 } & & $\begin{array}{c}\text { Wisatawan } \\
\text { Nusantara }\end{array}$ & $\begin{array}{c}\text { Wisatawan } \\
\text { Asing }\end{array}$ \\
\hline 2007 & 3.277 .073 & 63.802 & & $-3,9$ \\
\hline 2008 & 3.342 .044 & 61.301 & 2,0 & 1,6 \\
\hline 2009 & 3.632 .011 & 62.301 & 8,7 & 6,3 \\
\hline 2010 & 4.021 .239 & 66.223 & 10,7 & 7,5 \\
\hline 2011 & 4.542 .458 & 71.200 & 12,9 & \\
\hline
\end{tabular}

Sumber : Disbudpar Kabupaten Bandung, 2011

Berdasarkan Tabel 1.2 dapat dilihat bahwa jumlah wisatawan nusantara maupun asing yang datang berkunjung ke Kabupaten Bandung cenderung meningkat dari tahun ke tahun dengan rata-rata pertumbuhan $8,57 \%$ untuk wisatawan nusantara dan 2,9\% untuk wisatawan asing. Peningkatan tersebut dimungkinkan selain karena banyaknya pilihan kawasan wisata terutama di Bandung Selatan juga sebagai akibat dari membaiknya kualitas pelayanan baik dalam hal fasilitas maupun infrastruktur pendukung pengembangan pariwisata di daerah tersebut. Berdasarkan data dari Dinas Pariwisata Kabupaten Bandung tahun 2011, secara keseluruhan jumlah objek wisata yang ada di Bandung Selatan adalah 28 objek wisata. Sebagian besar pilihan wisatawan untuk berkunjung ke objek-objek wisata di kawasan Kabupaten Bandung adalah kemenarikan wisata alamnya yang asri dan belum tercemar polusi, namun selama ini masih ada anggapan bahwa beragamnya kemenarikan objek wisata di Bandung Selatan ini kurang didukung oleh penyediaan sarana penunjang untuk berwisata.

Wisatawan yang mengunjungi objek wisata hanya merasa terpenuhi keinginan untuk menikmati keasrian suatu objek wisata tanpa dipenuhi kebutuhan untuk aktivitas lainnya, karena kondisi dan ketersediaan fasilitas wisata yang kurang memenuhi harapan pengunjung. Selama ini upaya yang dilakukan oleh Disbudpar Kabupaten Bandung, dalam meningkatkan jumlah kunjungan wisatawan masih sebatas pada penyebaran booklet, leaflet dan pameran belum memaksimalkan kualitas tujuan wisata yang tentunya akan melibatkan kepentingan wisatawan sebagai konsumennya. Oleh karena itu Disbudpar Kabupaten Bandung dituntut untuk mengembangkan strategi pemasaran yang efektif, dimana strategi pemasaran harus disesuaikan menurut kebutuhan wisatawan, sehingga intensitas kunjungan wisatawan yang masuk ke Kabupaten Bandung semakin meningkat. Hal ini perlu dilakukan mengingat Kabupaten Bandung memiliki potensi wisata alam yang beragam dengan kualitas dan daya tarik yang dapat diandalkan. Salah satu destinasi wisata alam yang menjadi andalan dan banyak dikunjungi oleh wisatawan di Kabupaten Kabupaten Bandung adalah Pemandian Air Panas Ciwalini.

Pemandian Air Panas Ciwalini adalah sebuah tempat wisata yang menyediakan kolam renang, kamar mandi tertutup, permainan anak, wisata alam tea walk, bungalow, restaurant dan cottage dan perkebunan teh Walini yang tidak terpisahkan, produk-produk ini dikemas dengan baik yang dikelola oleh Puskopkar PTPN VIII. Pemandian Air Panas Ciwalini juga mempunyai fasilitas layanan untuk memberikan kenyamanan bagi pelanggannya seperti kolam renang I dan II, kolam rendam, restoran, bungalow, cottage, flying fox, water boom dan lainnya.

Kolam renang air panas Ciwalini terletak pada hamparan area perkebunan teh, dengan ketinggian $2000 \mathrm{~m}$ di atas permukaan air laut dan berjarak $60 \mathrm{~km}$ dari Kota Bandung. Kolam air panas ini sangat diinginkan oleh masyarakat untuk rekreasi, karena udaranya yang sejuk, pemandangan yang indah dan adanya Pemandian Air Panas Ciwalini memiliki potensi wisata alam 
yang tidak di ragukan lagi, dengan potensi setidaknya mampu menarik banyak para wisatawan.

Namun jumlah wisatawan lokal yang berkunjung ke Pemandian Air Panas ini Pemandian Air Panas Ciwalini Ciwalini menunjukkan kecenderungan yang menurun. Untuk lebih jelasnya dapat dilihat pada Tabel 1.3.

TABEL 1.3

DATA KUNJUNGAN WISATAWAN NUSANTARA KE TEMPAT PEMANDIAN AIR PANAS DI KABUPATEN BANDUNG

PERIODE 2007-2011

\begin{tabular}{|c|c|c|c|c|c|c|}
\hline \multirow{2}{*}{ Tahun } & \multicolumn{3}{|c|}{$\begin{array}{c}\text { Jumlah Pengunjung } \\
\text { (Orang) }\end{array}$} & \multicolumn{3}{c|}{$\begin{array}{c}\text { Pertumbuhan } \\
\text { (\%) }\end{array}$} \\
\cline { 2 - 7 } & Ciwalini & Cimanggu & Cibolang & Ciwalini & Cimanggu & Cibolang \\
\hline 2007 & 121.783 & 85.792 & 32.021 & - & - & - \\
\hline 2008 & 116.348 & 91.430 & 33.572 & $-4,5$ & 6,57 & 4,8 \\
\hline 2009 & 142.318 & 156.149 & 30.147 & 22,3 & 70,78 & $-10,2$ \\
\hline 2010 & 135.021 & 114.171 & 31.279 & $-5,1$ & $-26,88$ & 3,8 \\
\hline 2011 & 132.478 & 126.783 & 31.339 & $-1,9$ & 11,04 & 0,2 \\
\hline
\end{tabular}

Sumber : Disbudpar Kabupaten Bandung, 2011

Berdasarkan Tabel 1.3 dapat dilihat bahwa dari tiga tempat wisata alam yang sejenis di kawasan wisata Kabupaten Bandung, menunjukkan hasil yang bervariasi dalam menyerap wisatawan, tempat pemandian air panas Cimanggu masih menjadi tempat pilihan utama wisatawan. Masih relatif tingginya jumlah wisatawan yang berkunjung ke Cimanggu disebabkan karena selain lokasinya strategis yang tepat berada dipinggir jalan utama juga karena memiliki tempat pemandian air panas yang lebih luas serta fasilitas pendukung lainnya yang cukup lengkap dan wisatawan dapat menikmati kapan saja karena dibuka selama 24 jam setiap hari. Kondisi ini yang menyebabkan jumlah wisatawan pada tahun 2009 yang datang lebih banyak ke Cimanggu dibandingkan ke Ciwalini maupun Cibolang. Salah satu hal yang menarik dari ketiga tempat wisata alam yang sejenis tersebut adalah Ciwalini yang secara berturut-turut dari tahun 2009 sampai tahun 2011 yang mengalami penurunan jumlah pengunjung dibandingkan kedua tempat pemandian air panas lainnya pada tahun 2011 justru mengalami kenaikan jumlah pengunjung. Kondisi ini juga dapat mengindikasikan bahwa keputusan wisatawan untuk melakukan kunjungan ke pemandian air panas Ciwalini mengalami penurunan.

Penurunan jumlah kunjungan ke objek wisata Air Panas Ciwalini selain karena tingkat persaingan dengan objek wisata alam yang lokasinya dekat dengan wisata Air Panas Ciwalini juga karena adanya objek wisata baru yang menampilkan beragam atraksi menarik terutama bagi keluarga, sehingga menyebabkan wisatawan berpindah ke objek wisata lain. Untuk menjaga dan meningkatkan agar pengunjung tetap tertarik dan mau berkunjung ke objek wisata Air Panas Ciwalini, maka pihak pengelola membutuhkan langkah-langkah strategis dalam mengelola dan memasarkan produk jasa wisatanya. Strategi yang dilakukan oleh pengelola selain melalui penyebaran booklet, leaflet dan pameran wisata yang rutin diikuti oleh pengelola pemandian air panas Ciwalini adalah pemeran di Dinas Kebudayaan dan Pariwisata Kabupaten Bandung dan Jawa Barat yang rutin dilakukan dalam setiap tahun. Strategi lainnya yang juga tak kalah penting untuk meningkatkan jumlah kinjungan adalah pengelolaan bukti fisik (physical evidence) di dalam objek wisata itu sendiri, seperti perbaikan akses jalan, penambahan kolam renang untuk anak-anak dan penambahan fasilitas pendukung seperti warung sovenir merupakan upaya serius dari pengelola untuk menjadikan pemandian air panas Ciwalini sebagai pilihan utama wisata alam.

Physical Evidence atau bukti fisik merupakan lingkungan fisik tempat jasa diciptakan dan langsung berinteraksi dengan konsumen. Dalam industri jasa wisata, mengelola physical evidence dengan mencoba menggunakan unsur yang tangible untuk memperkuat arti atau nilai pokok intangible merupakan strategi yang penting dalam pemasaran jasa. Zeithaml at al (2013:278) menyebutkan bahwa physical evidence dapat dilihat dari Facility Exterior 
(Exterior design, signage, parking, landscape, surrounding environment), Facility Interior (Interior design, equipment, signage, layout, Air quality/temperature, Sound/music/lighting), Other Tangibles (Business cards, Stationery, Billing statements, Reports, Employee dress, Uniforms, Brochures, Web page, Virtual servicescape).

Physical evidence dalam objek wisata Pemandian Air Panas Ciwalini lebih ditujukan kepada penampilan fisik sarana wisata seperti kerapihan, kebersihan, kelengkapan, kelancaran, penampilan petugas, dan lain-lain. Hasil observasi dan wawancara awal dengan Bapak H. Dadang selaku pengelola Pemandian Air Panas Ciwalini dari Puskopkar PTPN VIII didapat informasi bahwa, aspek physical evidence objek wisata alam Air Panas Ciwalini (sarana prasana fasilitas pendukung kondisi atau interior design bangunan termasuk tata letak seperti kondisi jalan menuju lokasi pondokan wisata, ruang pertemuan, dan sarana lainnya) pada umumnya masih belum optimal.

Physical Evidence (bukti fisik) sangat penting dalam membentuk image atau persepsi karena melalui bukti fisik ini konsumen siap untuk mengidentifikasikan dan membandingkan suatu perusahaan jasa dengan perusahaan jasa lainnya sehingga dalam pengambilan keputusan penggunaan jasa konsumen tidak salah pilih. Van Der Merwe (2006) dalam penelitiannya menyebutkan "Jasa pariwisata pada dasarnya tidak berwujud, sehingga pelanggan sering mengandalkan bukti fisik di lingkungan layanan untuk mengevaluasi kualitas layanan. Lingkungan fisik juga dapat mempengaruhi pilihan pelanggan, harapan, perilaku pembelian dan kepuasan dengan organisasi pariwisata".

Berdasarkan uraian tersebut di atas, maka penulis perlu untuk melakukan penelitian tentang: "PENGARUH PHYSICAL EVIDENCE PEMANDIAN AIR PANAS CIWALINI TERHADAP KEPUTUSAN BERKUNJUNG (Survei pada Wisatawan Nusantara Pemandian Air Panas Ciwalini-Ciwidey Kabupaten Bandung)".

\section{KERANGKA PEMIKIRAN DAN HIPOTESIS}

\subsection{Kerangka Pemikiran}

Pemasaran merupakan serangkaian aktifitas perusahaan yang saling berhubungan, sehingga konsumen dapat memenuhi kebutuhan dan keinginannya, begitu pula dalam pemasaran industri pariwisata. Pemasaran pariwisata (tourism marketing) dapat dipahami sebagai proses pemilihan dan penerapan salah satu strategi perusahaan.

Pemasaran produk pariwisata yang merupakan pemasaran yang bergerak di bidang jasa jauh lebih kompleks sifatnya karena mempunyai karakteristik spesifik yang berbeda dibandingkan dengan pemasaran produk perusahaan manufaktur yang umumnya berbentuk atau berwujud. Pemahaman akan kompleksitas sifat produk pariwisata merupakan prasyarat esensial untuk mencapai pemasaran yang berhasil.

Salah satu komponen penting dari bauran pemasaran jasa yang terkait dengan industri pariwisata adalah physical evidence, karena komponen ini dapat memberikan kesempatan istimewa kepada perusahaan dalam mengirimkan pesan-pesan yang kuat dan konsisten berkenaan dengan apayang ingin dicapai, diberikan perusahaan kepada segmen pasar yang dituju, serta pesan-pesan berkenaan dengan karakteristik jasa yang dimiliki. Selain itu bukti fisik juga sangat penting dalam membentuk image atau persepsi karena melalui bukti fisik ini konsumen siap untuk mengidentifikasikan dan membandingkan suatu perusahaan jasa dengan perusahaan jasa lainnya.

Zeithaml, Bitner and Gremler (2013:26), mendefinisikan physical evidence sebagai "The environment in which the service is delivered and where firm and costumer interact and any tangible component that facilitate performance or communication of the service".

Zeithaml, et al (2013:278) menyebutkan elemen pokok dari physical evidence adalah facility exterior (fasilitas eksterior), facility interior (fasilitas interior) dan other tangibles. Penampilan dan kemampuan sarana prasarana fisik perusahaan dan keadaan lingkungan sekitarnya adalah bukti nyata dari pelayanan yang diberikan perusahaan. Physical Evidence (bukti fisik) sangat penting dalam membentuk image atau persepsi karena melalui bukti fisik ini konsumen siap untuk mengidentifikasikan dan membandingkan suatu perusahaan jasa dengan perusahaan jasa lainnya sehingga dalam pengambilan keputusan penggunaan jasa konsumen tidak salah pilih. Karena jasa tidak dapat diamati secara langsung, maka pelanggan seringkali 
berpedoman pada kondisi yang terlihat mengenai jasa dalam melakukan evaluasi pembelian.

Zeithaml, Bitner and Gremler (2013:278) menyatakan bahwa : "Customers often rely on tangibles cues, or physical evidence, to evaluate the service before its purchase and to assess their satisfaction with the service during and after consumption". Pendapat lainnya diungkapkan oleh Ratih Hurriyati (2008:64), bahwa sarana fisik yang menarik dapat digunakan untuk menjaring pelanggan dari target pasar yang ditentukan.

Kotler \& Keller (2012:161) menyatakan "In the evaluation stage, the consumers from preferences among the brands in the choice set and may also from an intention to buy the most preferred brand". Dalam tahap evaluasi, preferensi konsumen terhadap berbagai pilihan merek dan mungkin juga ada niat untuk membeli merek yang paling disukai.

Keputusan untuk membeli timbul karena adanya penilaian objektif ataukarena dorongan emosi. Keputusan untuk bertindak adalah hasil dari serangkaianaktivitas dan rangsangan mental emosional. Proses untuk menganalisa, merasakandan memutuskan, pada dasarnya adalah sama seperti seorang individu dalammemecahkan banyak permasalahannya. Konsumen membentuk preferensi atasmerek-merek dalam kumpulan pilihan pada saat tahap evaluasi. Konsumen jugamungkin membentuk niat untuk membeli produk yang paling disukai. Keputusankonsumen untuk memodifikasi, menunda, atau menghindari suatu keputusanpembelian sangat dipengaruhi oleh risiko yang dirasakan.

Keputusan pembelian menurut Kotler \& Keller (2012:161) memiliki dimensi, yaitu : pemilihan produk, pemilihan merek, pemilihan penyalur, jumlah pembelian, penentuan waktu pembelian dan pemilihan metode pembayaran. Dalam penelitian ini dimensi dari keputusan pembelianyang diadopsi menjadi keputusan berkunjung hanya empat dimensi keputusan yang digunakan yaitu pemilihan produk, pemilihan merek, jumlah kunjungan, pemilihan penyalur dan penentuan waktu pembelian, karena disesuaikan dengan situasi dan kondisi di Pemandian Air Panas Ciwalini.

\subsection{Hipotesis}

Berdasarkan premis-premis tersebut, maka hipotesis dalam penelitian ini dapat dirumuskan, terdapat pengaruh yang signifikan antara physical evidence terhadap keputusan berkunjung wisatawan nusantara di Pemandian Air Panas Ciwalini Kabupaten Bandung. Sedangkan sub hipotesisnya adalah :

1. Terdapat pengaruh antara Facility exterior terhadap keputusan berkunjung wisatawan nusantara di Pemandian Air Panas Ciwalini Kabupaten Bandung

2. Terdapat pengaruh antara Facility Interior terhadap keputusan berkunjung wisatawan nusantara di Pemandian Air Panas Ciwalini Kabupaten Bandung

3. Terdapat pengaruh antara Other tangibles terhadap keputusan berkunjung wisatawan nusantara di Pemandian Air Panas Ciwalini Kabupaten Bandung.

\section{METODE PENELITIAN}

\subsection{Objek Penelitian}

Objek penelitian merupakan suatu tanggapan dari responden tentang dari variabel independent (X) (variabel bebas) mengenai physical evidence yang terdiri dari facility exterior (X1), facility interior (X2) dan other tangibles (X3) terhadap keputusan berkunjung. Sedangkan yang menjadi variabel dependent (Y) (variabel terikat) yaitu keputusan berkunjung yang terdiri pemilihan produk, pemilihan merek, pemilihan penyalur, jumlah kunjungan dan waktu berkunjung pada Pemandian Air Panas Ciwalini. Pada penelitian ini yang menjadi responden, yaitu wisatawan nusantara yang berkunjung ke Pemandian Air Panas Ciwalini. Tujuan dari penelitian ini, yaitu untuk mengetahui pengaruh physical evidence terhadap keputusan berkunjung wisatawan.

\subsection{Metode Penelitian}

Pendekatan yang digunakan dalam penelitian ini adalah pendekatan cross sectional, yaitu "Metode penelitian dengan cara mempelajari objek dalam satu kurun waktu tertentu/tidak berkesinambungan dalam jangka waktu panjang" (Husein Umar, 2010:131). Metode ini diharapkan peneliti dapat mengungkapkan serta mengkaji seberapa besar physical evidence 
terhadap keputusan berkunjung wisatawan pada Pemandian Air Panas Ciwalini. Berdasarkan variable-variabel yang diteliti maka jenis penelitian ini adalah penelitian deskriptif dan verifikatif. Melalui jenis penelitian deskriptif maka dapat diperoleh deskripsi mengenai physical evidence pada objek wisata Pemandian Air Panas Ciwalini serta persepsi responden tentang keputusan berkunjung.

\subsubsection{Operasionalisasi variabel}

Operasional variabel merupakan batasan atau arti suatu konstruk atau variabel dengan merinci hal-hal yang harus dikerjakan oleh peneliti untuk mengukur variabel tersebut. Adapun variabel-variabel yang akan diuji adalah pengaruh physical evidence terhadap keputusan berkunjung. Secara lebih rinci operasionalisasi masingmasing variabel itu dapat terlihat dalam Tabel 3.1 berikut

Tabel 3.1

Operasionalisasi Variabel Penelitian

\begin{tabular}{|c|c|c|c|c|c|c|}
\hline Variabel & Konsep Variabel & $\begin{array}{c}\text { Sub } \\
\text { Variabel } \\
\end{array}$ & Indikator & Ukuran & Skala & $\begin{array}{l}\text { No. } \\
\text { Item }\end{array}$ \\
\hline & & & \multirow[t]{2}{*}{ Exterior design } & $\begin{array}{l}\text { Tingkat kemenarikan } \\
\text { gedung/bangunan } \\
\text { luar }\end{array}$ & Ordinal & C. 1.1 \\
\hline & & & & $\begin{array}{l}\text { Tingkat keunikan } \\
\text { gedung/bangunan } \\
\text { luar }\end{array}$ & Ordinal & C. 1.2 \\
\hline & & & \multirow[t]{2}{*}{$\begin{array}{l}\text { Signage } \\
\text { (tanda/logo/simbol/papan } \\
\text { merek) }\end{array}$} & $\begin{array}{l}\text { Tingkat kejelasan } \\
\text { tanda atau papan } \\
\text { nama }\end{array}$ & Ordinal & C. 1.3 \\
\hline & & & & $\begin{array}{l}\text { Daya tarik tanda atau } \\
\text { papan nama }\end{array}$ & Ordinal & C. 1.4 \\
\hline & & & \multirow[t]{3}{*}{ Parking (tempat parkir) } & $\begin{array}{l}\text { Tingkat kemudahan } \\
\text { parkir }\end{array}$ & Ordinal & C. 1.5 \\
\hline & & & & $\begin{array}{l}\text { Tingkat kenyamanan } \\
\text { parkir }\end{array}$ & Ordinal & C. 1.6 \\
\hline & & & & $\begin{array}{ll}\text { Tingkat } & \text { keluasan } \\
\text { area parkir } & \\
\end{array}$ & Ordinal & C. 1.7 \\
\hline & & & Landscape (pemandangan) & $\begin{array}{lr}\begin{array}{l}\text { Daya } \\
\text { pemandangan }\end{array} & \text { tarik } \\
\text { Pemandian } & \text { Air } \\
\text { Panas Ciwalini } & \\
\end{array}$ & Ordinal & C. 1.8 \\
\hline & & & \multirow[t]{2}{*}{$\begin{array}{l}\text { Surrounding environment } \\
\text { (lingkungan sekitar) }\end{array}$} & $\begin{array}{l}\text { Tingkat kenyamanan } \\
\text { lingkungan sekitar }\end{array}$ & Ordinal & C.1.9 \\
\hline & & & & $\begin{array}{l}\text { Tingkat kebersihan } \\
\text { lingkungan sekitar }\end{array}$ & Ordinal & C. 1.10 \\
\hline & & \multirow{4}{*}{$\begin{array}{l}\text { Facility interior } \\
\text { (fasilitas } \\
\text { interior) }\end{array}$} & \multirow[t]{2}{*}{ Interior design } & $\begin{array}{l}\text { Daya tarik interior } \\
\text { design }\end{array}$ & Ordinal & C. 2.11 \\
\hline & & & & $\begin{array}{l}\text { Tingkat keunikan } \\
\text { interior design }\end{array}$ & Ordinal & C. 2.12 \\
\hline & & & \multirow[t]{2}{*}{ Equipment (perlengkapan) } & $\begin{array}{l}\text { Tingkat ketersediaan } \\
\text { perlengkapan sarana } \\
\text { di pemandian air } \\
\text { panas Ciwalini }\end{array}$ & Ordinal & C. 2.13 \\
\hline & & & & $\begin{array}{l}\text { Tingkat kelayakan } \\
\text { perlengkapan di } \\
\text { pemandian air panas } \\
\text { Ciwalini }\end{array}$ & Ordinal & C. 2.14 \\
\hline
\end{tabular}




\begin{tabular}{|c|c|c|c|c|c|c|}
\hline Variabel & Konsep Variabel & $\begin{array}{c}\text { Sub } \\
\text { Variabel }\end{array}$ & Indikator & Ukuran & Skala & $\begin{array}{l}\text { No. } \\
\text { Item }\end{array}$ \\
\hline & & & \multirow[t]{3}{*}{ Layout (tata ruang) } & $\begin{array}{l}\text { Tingkat kesesuaian } \\
\text { tata letak kolam } \\
\text { renang }\end{array}$ & Ordinal & C. 2.15 \\
\hline & & & & $\begin{array}{l}\text { Tingkat kesesuaian } \\
\text { tata letak kolam } \\
\text { rendam tertutup }\end{array}$ & Ordinal & C. 2.16 \\
\hline & & & & $\begin{array}{l}\text { Tingkat kesesuaian } \\
\text { tata letak kamar bilas }\end{array}$ & Ordinal & C.2.17 \\
\hline & & \multirow[t]{6}{*}{ Other tangibles } & Ruang ganti & $\begin{array}{l}\text { Tingkat kenyamanan } \\
\text { ruang ganti }\end{array}$ & Ordinal & C. 3.20 \\
\hline & & & \multirow[t]{3}{*}{$\begin{array}{l}\text { Employee dress (pakaian } \\
\text { pegawai) }\end{array}$} & $\begin{array}{l}\text { Daya tarik pakaian } \\
\text { kerja karyawan }\end{array}$ & Ordinal & C.3.21 \\
\hline & & & & $\begin{array}{lr}\text { Tingkat } & \text { kerapihan } \\
\text { pakaian } & \text { kerja } \\
\text { karyawan } & \\
\end{array}$ & Ordinal & C. 3.22 \\
\hline & & & & $\begin{array}{lr}\text { Tingkat } & \text { kesesuaian } \\
\text { pakaian } & \text { kerja } \\
\text { karyawan } & \\
\end{array}$ & Ordinal & C. 3.23 \\
\hline & & & \multirow[t]{2}{*}{ Brochures (brosur) } & $\begin{array}{ll}\text { Tingkat } & \text { kejelasan } \\
\text { informasi } & \\
\end{array}$ & Ordinal & C. 3.24 \\
\hline & & & & $\begin{array}{l}\text { Tingkat kemenarikan } \\
\text { brosur }\end{array}$ & Ordinal & C. 3.25 \\
\hline \multirow[t]{9}{*}{$\begin{array}{l}\text { Keputusan } \\
\text { Berkunjung } \\
\text { (Y) }\end{array}$} & \multirow{9}{*}{$\begin{array}{l}\text { In the evaluation } \\
\text { stage, the } \\
\text { consumers from } \\
\text { preferences } \\
\text { among the brands } \\
\text { in the choice set } \\
\text { and may also } \\
\text { from an intention } \\
\text { to buy the most } \\
\text { preferred brand. } \\
\text { (Kotler \& Keller, } \\
\text { 2012:170) }\end{array}$} & & \multirow[t]{2}{*}{ Pemilihan produk } & $\begin{array}{l}\text { Tingkat keunggulan } \\
\text { produk }\end{array}$ & Ordinal & D.1.1 \\
\hline & & & & Daya tarik produk & Ordinal & D.1.2 \\
\hline & & & \multirow[t]{2}{*}{ Pemilihan merek } & $\begin{array}{lr}\text { Tingkat pemilihan } \\
\text { berdasarkan } & \text { citra } \\
\text { Pemandian } & \text { Air } \\
\text { Panas Ciwalini } & \\
\end{array}$ & Ordinal & D.1.3 \\
\hline & & & & $\begin{array}{l}\text { Tingkat pemilihan } \\
\text { berdasarkan } \\
\text { kepopuleran } \\
\text { Pemandian Air } \\
\text { Panas Ciwalini }\end{array}$ & Ordinal & D.1.4 \\
\hline & & & \multirow[t]{2}{*}{ Pemilihan penyalur } & $\begin{array}{l}\text { Tingkat pemilihan } \\
\text { berdasarkan lokasi } \\
\text { strategis }\end{array}$ & Ordinal & D.1.5 \\
\hline & & & & $\begin{array}{l}\text { Tingkat kemudahan } \\
\text { akomodasi dalam } \\
\text { menjangkau lokasi }\end{array}$ & Ordinal & D.1.6 \\
\hline & & & Jumlah Kunjungan & $\begin{array}{lr}\text { Intensitas melakukan } \\
\text { kunjungan } & \text { ke } \\
\text { Pemandian } & \text { Air } \\
\text { Panas Ciwalini pada } \\
\text { waktu sebulan }\end{array}$ & Ordinal & D.1.7 \\
\hline & & & \multirow[t]{2}{*}{ Penentuan waktu berkunjung } & $\begin{array}{l}\text { Intensitas melakukan } \\
\text { kunjungan pada saat } \\
\text { weekend }\end{array}$ & Ordinal & D. 1.8 \\
\hline & & & & $\begin{array}{l}\text { Intensitas melakukan } \\
\text { kunjungan pada saat }\end{array}$ & Ordinal & D.1.9 \\
\hline
\end{tabular}




\begin{tabular}{|l|l|l|l|l|l|l|}
\hline Variabel & Konsep Variabel & $\begin{array}{c}\text { Sub } \\
\text { Variabel }\end{array}$ & Indikator & \multicolumn{1}{c|}{ Ukuran } & Skala & $\begin{array}{c}\text { No. } \\
\text { Item }\end{array}$ \\
\hline & & & & hari libur besar & & \\
\cline { 4 - 7 } & & & $\begin{array}{l}\text { Intensitas melakukan } \\
\text { kunjungan pada saat } \\
\text { weekday }\end{array}$ & Ordinal & D.1.10 \\
\cline { 4 - 7 } & & & $\begin{array}{l}\text { Intensitas melakukan } \\
\text { kunjungan pada saat } \\
\text { ada promosi }\end{array}$ & Ordinal & D.1.11 \\
\hline
\end{tabular}

Sumber: Hasil pengolahan data, 2012

\subsubsection{Metode Penarikan Sampel}

Polulasi dalam penelitian ini adalah seluruh karakteristik yang mempengaruhi keputusan berkunjung tersebut, dan anggota polulasinya adalah seluruh pengunjung objek wisata alam Pemandian Air Panas Ciwalini yang berjumlah 132.478 tahun 2011.

Sampel adalah bagian dari jumlah dan karakteristik yang dimiliki oleh populasi tersebut (Sugiyono, 2012:120), untuk pengambilan sampel dari populasi, agar diperoleh sampel yang presentatif mewakili, maka diupayakan setiap subjek dalam populasi mempunyai peluang yang sama untuk menjadi sampel. Menurut Sugiyono (2012:120), "Bila populasi besar dan peneliti tidak mungkin mempelajari semua yang ada pada populasi, misalnya karena keterbatasan dana, tenaga, dan waktu, maka peneliti dapat menggunakan sampel yang diambil dari populasi itu. Apa yang dipelajari dari sampel itu kesimpulannya akan diberlakukan untuk populasi. Untuk itu sampel dari populasi harus benar-benar mewakili”.

Berdasarkan pengertian sampel yang dikemukakan di atas, maka sampel yang digunakan dalam penelitian ini adalah sebagian dari populasi penelitian, yaitu sebagian pengunjung wisata alam Pemandian Air Panas Ciwalini. Adapun rumus yang digunakan untuk mengukur sampel, digunakan rumus Slovin (Husein Umar, 2010:146), yakni ukuran sampel yang merupakan perbandingan dari ukuran populasi dengan presentasi kelonggaran ketidaktelitian, karena dalam pengambilan sampel dapat ditolerir atau diinginkan. Dalam pengambilan sampel ini digunakan taraf kesalahan sebesar 10\%. Adapun rumus yang digunakan yaitu sebagai berikut:

$$
\begin{gathered}
\mathrm{N}=\frac{132.478}{1+132.478(0,10)^{2}} \\
\mathrm{n}=100
\end{gathered}
$$

Berdasarkan hasil perhitungan di atas maka jumlah sampel yang diteliti yaitu sebanyak 100 responden. Teknik sampling yang digunakan yaitu dengan menggunakan Non probability Sampling. Teknik ini tidak memberikan peluang/kesempatan yang sama bagi setiap unsur atau anggota populasi untuk dipilih menjadi sampel. Hal ini didasarkan pada pertimbangan bahwa pengunjung yang telah datang ke Pemandian Air Panas Ciwalini tidak datang kembali pada saat dilakukan penyebaran kuesioner. Secara spesifik teknik yang digunakan adalah Teknik Sampling Aksidental. Teknik ini menentukan sampel berdasarkan kebetulan, yaitu siapa saja yang kebetulan bertemu dengan peneliti yang dapat digunakan sebagai sampel, bila dipandang orang yang kebetulan ditemui itu cocok sebagai sumber data (Sugiyono, 2012:77).

\subsubsection{Teknik Pengumpulan Data}

Teknik pengumpulan data merupakan suatu proses pengadaan untuk keperluan penelitian dimana data yang terkumpul adalah untuk menguji hipotesis yang telah dirumuskan. Adapun teknik pengumpulan data yang penulis gunakan adalah:

1. Wawancara

Sebagai teknik komunikasi langsung dengan pimpinan Puskopkar PTPN VIII. Wawancara ini dilakukan kepada pihak manajemen untuk memperoleh data mengenai profil Pemandian Air Panas Ciwalini, pelanggan sasaran dan 
program promosi pemasaran khususnya physical evidence

2. Observasi

Observasi dilakukan dengan meninjau serta melakukan pengamatan langsung terhadap objek yang ditelitiyaitu wisata Pemandian Air Panas Ciwalini, khususnya mengenai physical evidence

3. Kuesioner/angket

Merupakan teknik pengumpulan data melalui penyebaran seperangkat daftar pertanyaan tertulis. Kuesioner berisi pertanyaan dan pernyataan mengenai karaktersitik pengunjung, pelaksanaan physical evidence serta keputusan berkunjung. Kuesioner ditujukan kepada pengunjung wisata alam Pemandian Air Panas Ciwalini.

4. Studi Literatur

Studi literatur merupakan usaha pengumpulan informasi yang berhubungan dengan teori-teori yang ada kaitannya dengan masalah variabel yang diteliti yang terdiri dari physical evidence serta keputusan berkunjung didapat melalui Perpustakaan UPI, STT Telkom, internet dan lain-lain

\subsubsection{Analisis Data dan Pengujian Hipotesis}

\section{$1 \quad$ Analisis Data Deskriptif}

Pada penelitian ini, digunakan dua jenis analisis, yaitu analisis deskriptif khususnya bagi variabel yang bersifat kualitatif dan analisis kuantitatif berupa pengujian hipotesis dengan menggunakan uji statistik. Analisis deskripif digunakan untuk melihat faktor penyebab, sedangkan analisis kuantitatif menitikberatkan dalam pengungkapan perilaku variabel penelitian. Dengan menggunakan kombinasi metode analisis tersebut dapat diperoleh generalisasi yang bersifat komprehensif. Analisis deskriptif digunakan untuk melihat faktor penyebab yang dalam penelitian ini analisis deskriptif yang digunakan antara lain:

1) Analisis deskriptif tentang physical evidence yang terdiri dari facility exterior $\left(\mathrm{X}_{1}\right)$, facility interior $\left(\mathrm{X}_{2}\right)$ dan other tangibles $\left(\mathrm{X}_{3}\right)$

2) Analisis deskriptif tentang keputusan berkunjung yang terdiri dari pemilihan produk, pemilihan merek, pemilihan penyalur, jumlah kunjungan dan waktu berkunjung.

Untuk menjawab deskripsi tentang masing-masing variabel penelitian di atas digunakan rentang kriteria penilaian. Selanjutnya untuk menetapkan peringkat dalam setiap variabel penelitian dapat dilihat dari urutan proses pencarian skor ideal tertinggi, skor ideal terendah, panjang interval kelas, dan tinjauan kontinum berdasarkan rumus dari Sugiyono (2010:94), yaitu :

a. Mencari skor maksimal variabel

Skor ideal $=$ skor tertinggi $\mathrm{x}$ jumlah butir item $\mathrm{x}$ jumlah responden

b. Mencari skor minimal variabel

Skor ideal $=$ skor terendah $\mathrm{x}$ jumlah butir item $\mathrm{x}$ jumlah responden

c. Mencari jenjang variabel

Jenjang $=$ skor maksimal - skor minimal

d. Mencari panjang interval kelas variabel Panjang interval kelas $=$ jenjang / banyak kelas interval

e. Membuat garis kontinum

\section{Pengujian Hipotesis}

Langkah terakhir dari analisis data yaitu menguji hipotesis dengan tujuan untuk mengetahui apakah terdapat hubungan yang cukup jelas dan dapat dipercaya anatara variabel independen dengan variabel dependen, yang pada akhirnya akan diambil suatu kesimpulan $\mathrm{Ho}$ ditolak atau $\mathrm{Ha}$ diterima dari hipotesis yang telah dirumuskan. Pengujian hipotesis dalam penelitian ini akan diuji melalui analisis jalur. Pengujian hipotesis dilakukan dengan langkah-langkah sebagai berikut:

1. Menggambar struktur hipotesis

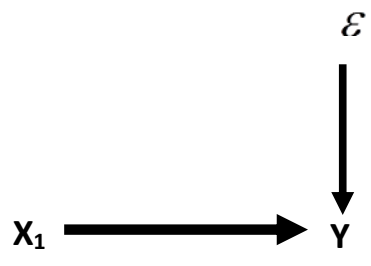

GAMBAR 3.1

DIAGRAM JALUR HIPOTESIS 
a. Selanjutnya diagram hipotesis di atas diterjemahkan ke dalam beberapa sub hipotesis dan untk lebih jelasnya dapat dilihat pada Gambar 3.2

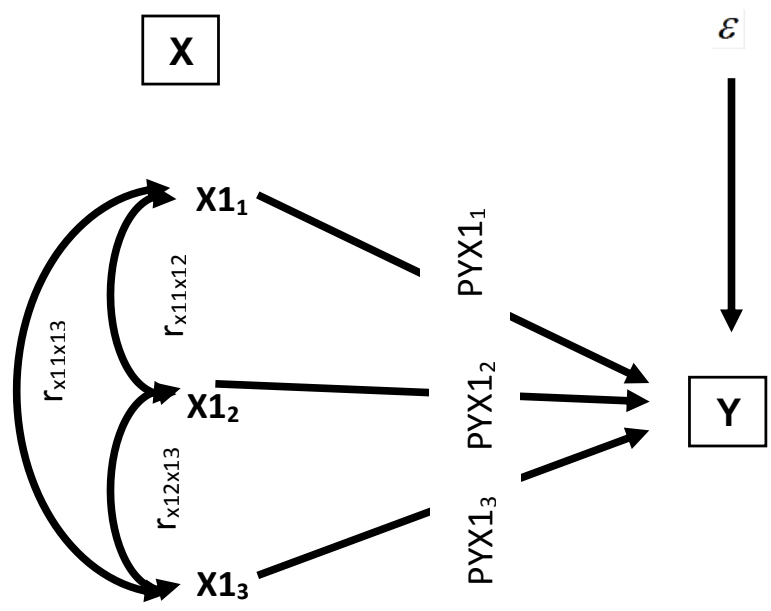

GAMBAR 3.2

DIAGRAM JALUR SUB STRUKTUR HIPOTESIS

b. Menghitung matriks korelasi antarvariabel bebas :

$$
\mathbf{R}_{\mathbf{1}}=\left[\begin{array}{ccc}
\mathbf{X}_{1.1} & \mathrm{X}_{1.2} & \mathbf{X}_{1.3} \\
\mathbf{1} & \mathbf{r} \mathbf{X}_{\mathbf{1 . 1}} \mathbf{X}_{\mathbf{1 . 2}} & \mathbf{r} \mathbf{X}_{\mathbf{1 . 1}} \mathbf{X}_{\mathbf{1 . 3}} \\
& \mathbf{1} & \mathbf{r} \mathbf{X}_{\mathbf{1 . 2}} \mathbf{X}_{\mathbf{1 . 3}}
\end{array}\right]
$$

c. Identifikasi persamaan sub struktur hipotesis

$$
\mathrm{Y}=\mathrm{Pyx}_{1} \mathrm{X}_{1.1}+\mathrm{Pyx}_{2} \mathrm{X}_{1.2}+\mathrm{Pyx}_{3} \mathrm{X}_{1.3}+\varepsilon
$$

d. Menghitung matriks invers kolerasi

$$
\mathbf{R}_{1}{ }^{-1}=\left[\begin{array}{lll}
\mathrm{X}_{1.1} & \mathrm{X}_{1.2} & \mathrm{X}_{1.3} \\
& \mathbf{C}_{1.1} & \mathbf{C}_{1.3} \\
& \mathbf{C}_{2.2} & \mathbf{C}_{.2 .3} \\
& & \mathbf{C}_{.3 .3}
\end{array}\right]
$$

e. Menghitung semua koefisien jalur melalui rumus :

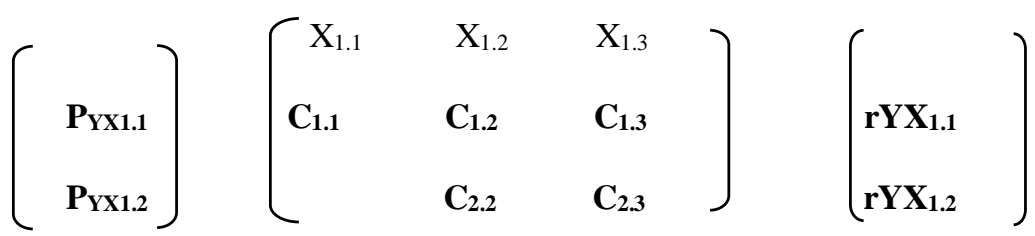


$\begin{array}{lll}\text { PYX1.3 }_{1.3} & \mathbf{C}_{3.3} & \text { PYX }_{1.3}\end{array}$

f. Hitung $R^{2} Y\left(X_{1.1}, X_{1.2}, X_{1.3}\right)$ yaitu koefisien yang menyatakan determinasi

$$
\mathrm{R}^{2} \mathrm{Y}\left(\mathrm{X}_{1.1}, \ldots, \mathrm{X}_{1.3}\right)=\left[\mathrm{P}_{\mathrm{YX} 1.1}, \ldots, \mathrm{P}_{\mathrm{YX} 1.3}\right]
$$

total $\mathrm{X}_{1.1}, \mathrm{X}_{1.2}, \mathrm{X}_{1.3}$, terhadap $\mathrm{Y}$ dengan menggunakan rumus :

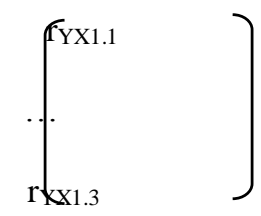

g. Statistik uji yang digunakan adalah:

$$
F=\frac{(n-k-1) \sum_{i=1}^{k} P_{Y X I} P_{Y X I}}{k\left(1-\sum_{i=1}^{k} P_{Y X i} P_{Y X i}\right)}
$$

Hasil $\mathrm{F}_{\text {hitung }}$ dibandingkan dengan tabel distribusi F-Snedecor, apabila $F_{\text {hitung }} \geq$ $F_{\text {tabel}}$, maka Ho ditolak dengan demikian

dapat diteruskan pada pengujian secara individual, statistik yang digunakan adalah:

$$
t=\frac{p_{Y X i}-p_{Y X i}}{\sqrt{\frac{\left(1-R_{Y(X 1, X 2, X 3)}^{2}\right)\left(C_{i i}+C_{i j}+C_{j j}\right)}{(n-k-1)}}}
$$

t mengikuti distribusi t-Student dengan derajat kebebasan n-k-1.
Menguji analisis langsung maupun tidak langsung dari setiap variabel :

\section{Analisis $\mathbf{X}$ terhadap $\mathbf{Y}$ :}

Analisis $\left(\mathbf{X}_{1}\right)$ terhadap $\mathbf{Y}$ :

Analisis langsung $\quad=\mathrm{PYX}_{1.1}$. $\mathrm{PYX}_{1.1}$

Analisis tidak langsung melalui $\left(\mathrm{X}_{2}\right)=\mathrm{PYX}_{1.1} \cdot \mathrm{rX}_{1.1} \mathrm{X}_{1.2} \cdot \mathrm{PYX}_{1.2}$

Analisis tidak langsung melalui $\left(\mathrm{X}_{3}\right)=\mathrm{PYX}_{1.1} \cdot \mathrm{rX}_{1.1} \mathrm{X}_{1.3} \cdot \mathrm{PYX}_{1.3}$

Analisis total $\left(\mathrm{X}_{1}\right)$ terhadap $\mathrm{Y}$

\section{Analisis $\left(\mathbf{X}_{2}\right)$ terhadap $Y$ :}

Analisis langsung $\quad=\mathrm{PYX}_{1.2}$. $\mathrm{PYX}_{1.2}$

Analisis tidak langsung melalui $\left(\mathrm{X}_{1}\right)=\mathrm{PYX}_{1.2} \cdot \mathrm{rX}_{1.2} \mathrm{X}_{1.1} \cdot \mathrm{PYX}_{1.1}$

Analisis tidak langsung melalui $\left(\mathrm{X}_{3}\right)=\mathrm{PYX}_{1.2} \cdot \mathrm{rX}_{1.2} \mathrm{X}_{1.3} \cdot \mathrm{PYX}_{1.3}$

Analisis total $\left(\mathrm{X}_{2}\right)$ terhadap $\mathrm{Y}$

Analisis $\left(\mathbf{X}_{3}\right)$ terhadap $\mathbf{Y}$ :

Analisis langsung

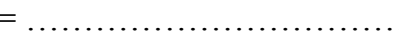

Analisis tidak langsung melalui $\left(\mathrm{X}_{1}\right)=\mathrm{PYX}_{1.3} \cdot \mathrm{rX}_{1.3} \mathrm{X}_{1.1} \cdot \mathrm{PYX}_{1.1}$

Analisis tidak langsung melalui $\left(\mathrm{X}_{2}\right)=\mathrm{PYX}_{1.3} \cdot \mathrm{rX}_{1.3} \mathrm{X}_{1.2} \cdot \mathrm{PYX}_{1.2}$

Analisis total $\left(\mathrm{X}_{3}\right)$ terhadap $\mathrm{Y}$

h. Menghitung pengaruh variabel lain $(\varepsilon)$

dengan rumus sebagai berikut:

$$
P_{Y \mathcal{E}}=\sqrt{1-R_{Y(X 11, X 12, X 13)}^{2}}
$$


i. Keputusan penerimaan atau penolakan Ho

Rumusan Hipotesis operasional:

Ho $\quad \mathrm{PYX}_{1.1}=\mathrm{PYX}_{1.2}=\mathrm{PYX}_{1.3}=0$

Hi : sekurang-kurangnya ada sebuah PYXi $\neq 0, \mathrm{i}=1,2$, dan 3

Kriteria pengambilan keputusan pengujian hipotesis secara statistik dalam rangka pengambilan keputusan penerimaan atau penolakan hipotesis dapat ditulis sebagai berikut :

Ho : $\rho_{i}<0$ Tidak terdapat pengaruh signifikan antara physical evidence yang terdiri dari facility exterior, facility interior dan other tangibles terhadap keputusan berkunjung

$\mathrm{H} a: \rho_{\mathrm{i}}>0$ Terdapat pengaruh positif yang signifikan antara physical evidence yang terdiri dari facility exterior, facility interior dan other tangibles terhadap keputusan berkunjung.
IV.

\subsection{Tanggapan Wisatawan Terhadap Physical Evidence}

Physical Evidence memberikan kesempatan istimewa kepada perusahaan dalam mengirimkan pesan-pesan yang kuat dan konsisten berkenaan dengan apa yang ingin dicapai, diberikan perusahaan kepada segmen pasar yang dituju, serta pesan-pesan berkenaan dengan karakteristik jasa yang dimiliki. Adapun Physical Evidence yang diteliti adalah sub variabel fasilitas eksterior, fasilitas interior dan other tangibles. Hasil akumulasi pernyataan pengunjung dapat dalam bentuk garis kontinum sebagai berikut

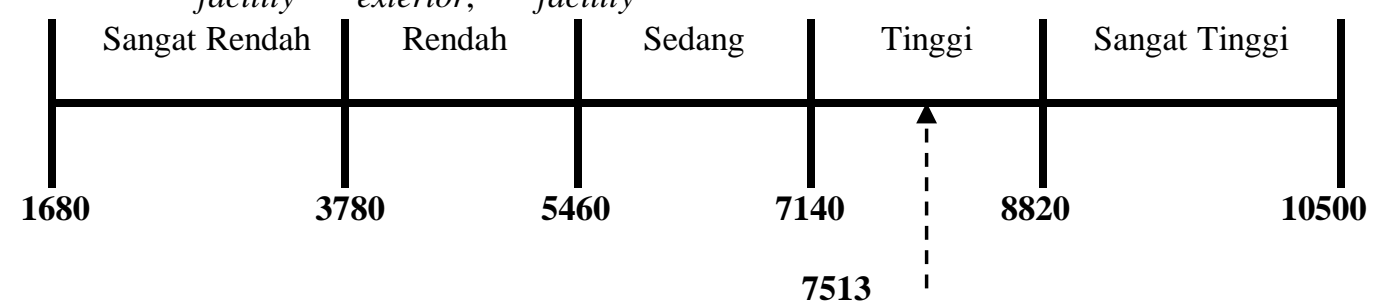

GAMBAR 4.1

TANGGAPAN PENGUNJUNG TERHADAP PHYSICAL EVIDENCE

Gambar 4.1 menjelaskan bahwa Physical Evidence pada Pemandian Air Panas Ciwalini secara keseluruhan mendapat penilaian pada kategori tinggi. Skor yang diperoleh Physical Evidence sebesar 7513 atau $\quad \bar{X}=\frac{7513}{10500}=71,6 \% \quad$ Hal ini menunjukan bahwa Pengelola Pemandian Air Panas Ciwalini berhasil menciptakan persepsi pengunjung terhadap Physical Evidence sebagai ukuran untuk menilai kepuasan yang dirasakan pengunjung dalam melakukan wisata alam.

Rekapitulasi mengenai hasil penilaian pengunjung terhadap pelaksanaan Physical Evidence didapat dari pengolahan data melalui kuesioner yang diberikan kepada pengunjung Pemandian Air Panas Ciwalini. Penilaian pengunjung terhadap Physical Evidence berada pada posisi penilaian yang baik. Hal tersebut dapat terlihat pada Tabel 4.10 sebagai berikut:

TABEL 4.4

REKAPITULASI HASIL PENILAIAN PHYSICAL EVIDENCE

\begin{tabular}{|ccccc|}
\hline No & Sub Variabel & Total Skor & Skor & $\%$ \\
& & & Rata-Rata & Skor \\
& & & 360,4 & 33,4 \\
\hline
\end{tabular}




\begin{tabular}{|llccc|}
\hline 2 & Sub Variabel Fasilitas Interior & 2145 & 350,3 & 32,0 \\
3 & Sub Variabel Fasilitas Lainnya & 1494 & 375,3 & 34,6 \\
Total & 7513 & 1078,9 & 100,0 \\
\hline
\end{tabular}

\section{Sumber :Hasil Pengolahan Data 2012}

Berdasarkan Tabel 4.4 terlihat bahwa sub variabel physical evidence yang mendapatkan penilaian tertinggi yaitu fasilitas lainnya sebesar 34,6\%, hal ini menunjukan bahwa fasilitas lainnya dirasakan oleh pengunjung sebagai hal yang paling benar-benar terasa selama pengunjung tersebut berada di Pemandian Air Panas Ciwalini. Sedangkan yang mendapat penilaian terendah adalah fasilitas eksterior, hal tersebut disebabkan karena pengunjung masih merasakan bahwa untuk mendapatkan parkir dirasakan masih sulit akibat dari terbatasnya fasilitas parkir.

\subsection{Tanggapan Wisatawan Terhadap Keputusan Berkunjung pada Objek Wisata Pemandian Air Panas Ciwalini \\ Keputusan berkunjung didasari pada} informasi tentang keunggulan suatu produk yang disusun sehingga menimbulkan rasa menyenangkan yang akan merubah seseorang untuk melakukan keputusan berkunjung. Keputusan berkunjung memiliki dimensi pemilihan produk/jasa, pemilihan merek, pemilihan waktu berkunjung dan jumlah kunjungan. Berdasarkan pada hasil pengolahan data dari angket yang telah disebarkan maka dapat dilihat posisi penilaian responden pada Gambar berikut ini:

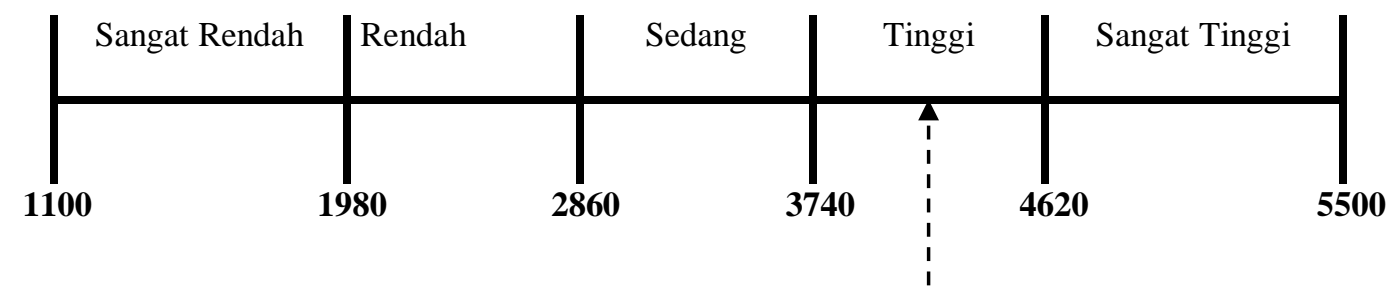

GAMBAR 4.2

TANGGAPAN PENGUNJUNG TERHADAP KEPUTUSAN BERKUNJUNG

Berdasarkan Gambar 4.12 dapat dilihat bahwa secara keseluruhan keputusan berkunjung mendapat penilaian pada kategori tinggi. Skor yang diperoleh keputusan berkunjung sebesar 4027 atau $\bar{Y}=\frac{4027}{5500}=73,2 \%$ Hal ini menunjukkan tingginya keputusan berkunjung wisatawan nusantara untuk dating berkunjung ke Pemandian Air Panas Ciwalini. Rekapitulasi keputusan berkunjung dapat dilihat pada Tabel 4.10 berikut:

TABEL 4.18

REKAPITULASI KEPUTUSAN BERKUNJUNG

\begin{tabular}{|c|l|c|c|c|}
\hline No & \multicolumn{1}{|c|}{ Dimensi } & Total Skor & $\begin{array}{c}\text { Skor } \\
\text { Rata-Rata }\end{array}$ & $\begin{array}{c}\text { \% } \\
\text { Skor }\end{array}$ \\
\hline 1 & Pemilihan Produk & 781 & 390,5 & 21.1 \\
\hline 2 & Pemilihan Merek & 733 & 366,5 & 19.8 \\
\hline 3 & Pemilihan Penyalur & 775 & 387,5 & 21.0 \\
\hline 4 & Jumlah Kunjungan & 360 & 360,0 & 19.5 \\
\hline
\end{tabular}




\begin{tabular}{|l|l|c|c|c|}
\hline 5 & Penentuan Waktu Kunjungan & 1378 & 344,5 & 18.6 \\
\hline Total & $\mathbf{4 0 2 7}$ & $\mathbf{1 8 4 9}$ & $\mathbf{1 0 0 , 0}$ \\
\hline
\end{tabular}

\section{Sumber :Hasil Pengolahan Data 2012}

Tabel 4.18 menunjukkan bahwa dimensi keputusan berkunjung yang menghasilkan skor tertinggi adalah pemilihan produk dan yang terendah adalah penentuan waktu kunjungan.

\subsection{Pengaruh Physical Evidence terhadap Keputusan Berkunjung Wisatawan pada Pemandian Air Panas Ciwalini}

Pengujian hipotesis dilakukan untuk mengetahui pengaruh physical evidence yang terdiri dari fasilitas eksterior $\left(\mathrm{X}_{1}\right)$, fasilitas interior $\left(\mathrm{X}_{2}\right)$ dan other tangibles $\left(\mathrm{X}_{3}\right)$ terhadap keputusan berkunjung (Y). Pengujian hipotesis dilakukan dengan menggunakan uji statistik path analysis (analisis jalur). Tabel 4.17 berikut menyajikan hasil perhitungan koefisien korelasi, antara setiap dimensi (sub variabel) $\mathrm{X}$ dengan $\mathrm{Y}$.

TABEL 4.24

MATRIKS KORELASI ANTAR SUB VARIABEL PHYSICAL EVIDENCE DAN KEPUTUSAN BERKUNJUNG Correlations

\begin{tabular}{|c|c|c|c|c|c|}
\hline & & $\overline{Y \_T O T}$ & $\times 1$ & $\times 2$ & $\times 3$ \\
\hline \multirow[t]{3}{*}{$\bar{Y} Y_{-}$TOT } & Pearson Correlation & $\overline{1}$ & $.376^{x x}$ & $.393^{\mathrm{xx}}$ & $.430^{x x}$ \\
\hline & Sig. (2-tailed) & & .000 & .000 & .000 \\
\hline & $N$ & 100 & 100 & 100 & 100 \\
\hline \multirow[t]{3}{*}{$\mathrm{X} 1$} & Pearson Correlation & $.376^{x x}$ & 1 & $.272^{\mathrm{xx}}$ & .173 \\
\hline & Sig. (2-tailed) & .000 & & .006 & .085 \\
\hline & $N$ & 100 & 100 & 100 & 100 \\
\hline \multirow[t]{3}{*}{$\times 2$} & Pearson Correlation & $.393^{x x}$ & $.272^{x \pi}$ & 1 & $.254^{\pi}$ \\
\hline & Sig. (2-tailed) & .000 & .006 & & .011 \\
\hline & $N$ & 100 & 100 & 100 & 100 \\
\hline \multirow[t]{3}{*}{$\mathrm{X} 3$} & Pearson Correlation & $.430^{\mathrm{xx}}$ & .173 & $.254^{\pi}$ & 1 \\
\hline & Sig. (2-tailed) & .000 & .085 & .011 & \\
\hline & $N$ & 100 & 100 & 100 & 100 \\
\hline
\end{tabular}

*. Correlation is significant at the 0.01 level (2-tailed).

*. Correlation is significant at the 0.05 level (2-tailed).

Hasil perhitungan matrik korelasi antar variabel menunjukkan tingkat hubungan sebagai berikut :

1. Fasilitas ekterior $\left(\mathrm{X}_{1}\right)$ dengan fasilitas interior $\left(\mathrm{X}_{2}\right)$ diperoleh koefisien korelasi sebesar 0,272 dengan tingkat signifikansi $0,006<0,05$. Koefisien tersebut menunjukkan bahwa fasilitas ekterior mempunyai hubungan yang signifikan dengan fasilitas interior.

2. Fasilitas ekterior $\left(\mathrm{X}_{1}\right)$ dengan fasilitas lainnya $\left(\mathrm{X}_{3}\right)$ diperoleh koefisien korelasi sebesar 0,173 dengan tingkat signifikansi $0,011>0,05$. Koefisien tersebut menunjukkan bahwa fasilitas ekterior tidak mempunyai hubungan yang signifikan dengan fasilitas lainnya.

3. Fasilitas interior $\left(\mathrm{X}_{2}\right)$ dengan fasilitas lainnya $\left(\mathrm{X}_{3}\right)$ diperoleh koefisien korelasi sebesar 0,254 dengan tingkat signifikansi $0,006<0,05$. Koefisien tersebut menunjukkan bahwa fasilitas interior mempunyai hubungan yang signifikan dengan fasilitas lainnya.

4. Fasilitas ekterior $\left(\mathrm{X}_{1}\right)$ dengan keputusan berkunjung (Y) diperoleh koefisien korelasi sebesar 0,376 dengan tingkat signifikansi $0,000<0,05$. Koefisien tersebut menunjukkan bahwa fasilitas 
ekterior mempunyai hubungan yang signifikan dengan keputusan berkunjung

5. Fasilitas interior $\left(\mathrm{X}_{2}\right)$ dengan keputusan berkunjung (Y) diperoleh koefisien korelasi sebesar 0,393 dengan tingkat signifikansi $0,000<0,05$. Koefisien tersebut menunjukkan bahwa fasilitas interior mempunyai hubungan yang signifikan dengan keputusan berkunjung

6. Fasilitas lainnya $\left(\mathrm{X}_{3}\right)$ dengan keputusan berkunjung (Y) diperoleh koefisien korelasi sebesar 0,430 dengan tingkat signifikansi $0,000<0,05$. Koefisien tersebut menunjukkan bahwa fasilitas lainnya mempunyai hubungan yang signifikan dengan keputusan berkunjung

Berdasarkan nilai koefisien korekasi di atas, maka variabel yang memiliki korelasi terbesar adalah fasilitas lainnya seperti ruang ganti, kelengkapan pakaian karyawan dan brosur dengan keputusan berkunjung yaitu sebesar 0.430. Koefisien tersebut menunjukkan bahwa antara fasilitas interior dengan keputusan berkunjung memiliki hubungan yang positif yang berarti baiknya fasilitas interior yang ada di Pemandian Air Panas Ciwalini akan diikuti dengan naiknya jumlah kunjungan. Sedangkan korelasi terendah antara variabel $\mathrm{X}$ dan variabel $\mathrm{Y}$ adalah fasilitas ekerior dengan keputusan berkunjung yaitu sebesar 0.376. Hal ini menunjukan bahwa fasilitas ekterior belum terlalu mempengaruhi dalam menarik pengunjung.

Secara lengkap struktural kausal antara variabel physical evidence yang terdiri dari fasilitas eksterior $\left(\mathrm{X}_{1}\right)$, fasilitas interior $\left(\mathrm{X}_{2}\right)$ dan other tangibles $\left(\mathrm{X}_{3}\right)$ terhadap keputusan berkunjung (Y) dapat dilihat pada Gambar 4.24 berikut.

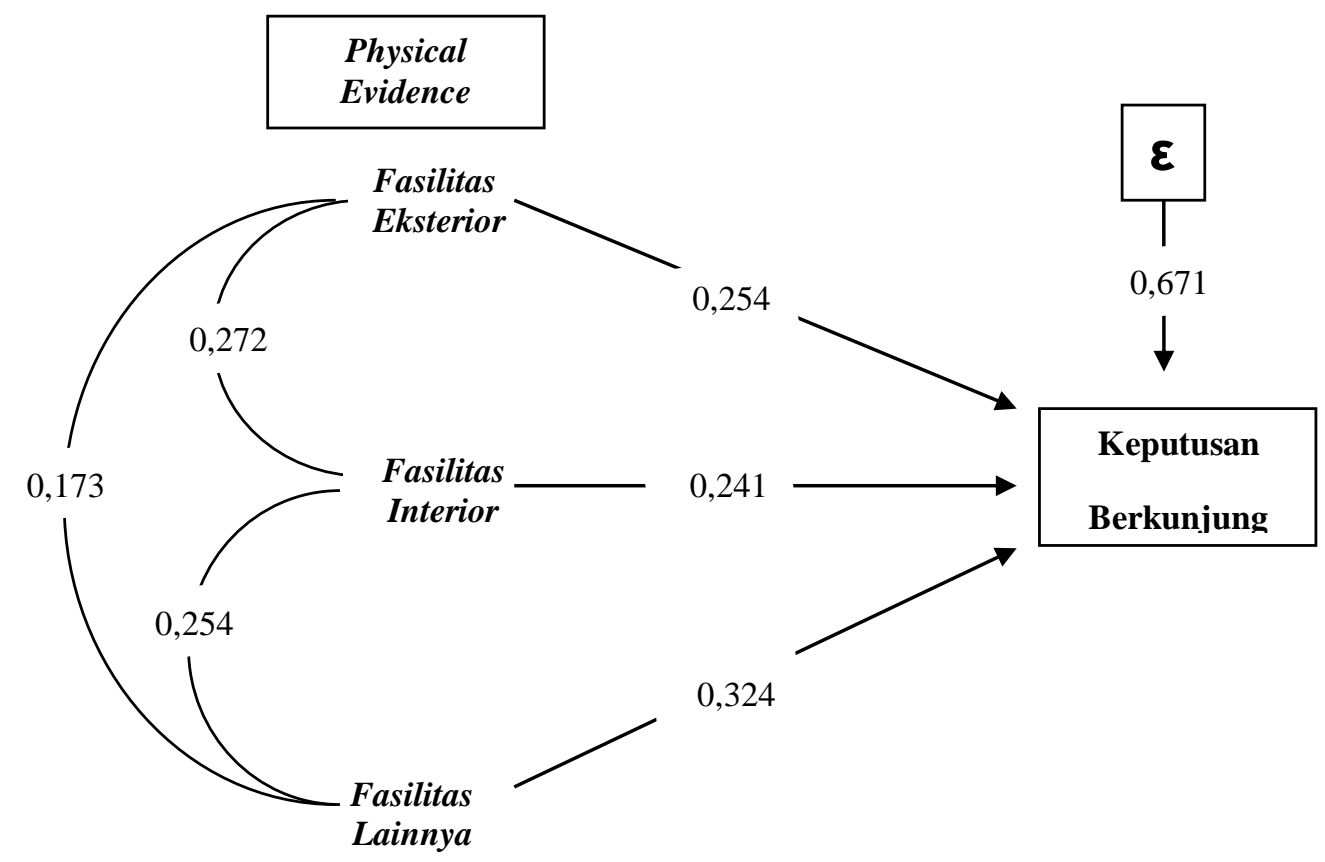

Sumber : Pengolahan Data 2012

Gambar 4.13 menggambarkan struktur hubungan kausal $\mathrm{X}_{1}, \mathrm{X}_{2}$, dan $\mathrm{X}_{3}$ terhadap $\mathrm{Y}$, dimana pengujian hipotesis dalam penelitian ini menggunakan analisis jalur. Analisis jalur digunakan untuk mengetahui pengaruh langsung dan tidak langsung antara fasilitas eksterior $\left(\mathrm{X}_{1}\right)$, fasilitas interior $\left(\mathrm{X}_{2}\right)$ dan other tangibles $\left(\mathrm{X}_{3}\right)$ terhadap keputusan berkunjung (Y). Untuk meningkatkan keputusan calon pengunjung untuk melakukan kunjungan, maka pengelola Pemandian Air Panas Ciwalini harus terus meningkatkan physical evidence. Sesuai dengan pendapat dari Zeithaml, Bitner and Gremler (2012:278) yang menyatakan bahwa : "Customers often rely on tangibles cues, or physical evidence, to evaluate the service before its purchase and to assess their satisfaction with the service during and after consumption". Pendapat lainnya 
diungkapkan oleh Ratih Hurriyati (2008:64), bahwa sarana fisik yang menarik dapat digunakan untuk menjaring pelanggan dari target pasar yang ditentukan.

Untuk menjawab permasalahan penelitian apakah physical evidence yang terdiri dari fasilitas eksterior $\left(\mathrm{X}_{1}\right)$, fasilitas interior $\left(\mathrm{X}_{2}\right)$ dan other tangibles $\left(\mathrm{X}_{3}\right)$ secara simultan berpengaruh terhadap keputusan berkunjung (Y). Pengujianhipotesis ini digunakan uji $\mathrm{F}$, berdasarkan hasil pengujian hipotesis melalui SPSS 19.0 pengujian secara keseluruhan (Uji F), disajikan dalam Tabel 4.25.

TABEL 4.25

UJI KESELURUHAN (UJI F)

ANOVA ${ }^{\mathrm{b}}$

\begin{tabular}{|ll|r|r|r|r|r|}
\hline Model & & \multicolumn{1}{c|}{$\begin{array}{c}\text { Sum of } \\
\text { Squares }\end{array}$} & df & Mean Square & \multicolumn{1}{c|}{ F } & Sig. \\
\hline 1 & Regression & 797.252 & 3 & 265.751 & 15.723 & $.000^{a}$ \\
& Residual & 1622.565 & 96 & 16.902 & & \\
& Total & 2419.817 & 99 & & & \\
\end{tabular}

a. Predictors: (Constant), $\times 3, \times 1, \times 2$

b. Dependent Variable: Y_TOT

Dari uji Anova atau F test, didapat nilai F hitung 15,723 dengan tingkat signifikansi 0.000. Karena probobilitas 0.000 jauh dibawah 0.05 maka model regresi dapat dipakai untuk memprediksi keputusan berkunjung atau bisa dikatakan secara bersama-sama fasilitas eksterior $\left(\mathrm{X}_{1}\right)$, fasilitas interior $\left(\mathrm{X}_{2}\right)$ dan other tangibles $\left(\mathrm{X}_{3}\right)$ mempengaruhi keputusan berkunjung. Oleh karena secara keseluruhan model fit dan bisa dilakukan uji secara parsial.
Pengujian parsial dilakukan untuk melihat kebermaknaan atau signifikansi pengaruh variabel independen physical evidence yang terdiri dari fasilitas eksterior $\left(\mathrm{X}_{1}\right)$, fasilitas interior $\left(\mathrm{X}_{2}\right)$ dan other tangibles $\left(\mathrm{X}_{3}\right)$ terhadap keputusan berkunjung (Y) secara parsial, maka dilakukan pengujian dengan uji-t dan hasilnya dapat dilihat pada Tabel 4.35

TABEL 4.26 COEFFICIENTS Coefficients $^{a}$

\begin{tabular}{|c|c|c|c|c|c|c|}
\hline \multirow{2}{*}{\multicolumn{2}{|c|}{ Model }} & \multicolumn{2}{|c|}{ Unstandardized Coefficients } & \multirow{2}{*}{$\begin{array}{c}\begin{array}{c}\text { Standardized } \\
\text { Coefficients }\end{array} \\
\text { Beta }\end{array}$} & \multirow[b]{2}{*}{$\mathrm{t}$} & \multirow[b]{2}{*}{ Sig. } \\
\hline & & $B$ & Std. Error & & & \\
\hline \multirow[t]{4}{*}{1} & (Constant) & 2.889 & 4.547 & & .635 & .527 \\
\hline & $\mathrm{x} 1$ & .283 & .097 & .254 & 2.903 & .005 \\
\hline & $\times 2$ & .435 & .160 & .241 & 2.713 & .008 \\
\hline & $\times 3$ & .798 & .214 & .324 & 3.730 & .000 \\
\hline
\end{tabular}

a. Dependent Variable: Y_TOT

Hasil pengujian hipotesis untuk melihat pengaruh parsial dapat diuraikan sebagai berikut :

1. Pengaruh fasilitas eksterior terhadap keputusan berkunjung ditunjukkan oleh koefisien jalur sebesar 0,254. Hasil perhitungan diperoleh $t_{\text {hitung }}$ sebesar 2,903 dengan tingkat signifikansi 0.005, karena probobilitas 0.005 dibawah 0.005 maka dapat disimpulkan ada pengaruh yang signifikan dari fasilitas ekterior terhadap keputusan berkunjung.

2. Pengaruh fasilitas interior terhadap keputusan berkunjung ditunjukkan oleh koefisien jalur sebesar 0,241. Hasil perhitungan diperoleh $t_{\text {hitung }}$ sebesar 
2,713 dengan tingkat signifikansi 0.008, karena probobilitas 0.005 jauh dibawah 0.005, maka dapat disimpulkan ada pengaruh yang signifikan dari fasilitas interior terhadap keputusan berkunjung.

3. Pengaruh fasilitas lainnya terhadap keputusan berkunjung ditunjukkan oleh koefisien jalur sebesar 0,324. Hasil perhitungan diperoleh $t_{\text {hitung }}$ sebesar 3,730

dengan tingkat signifikansi 0.000, karena probobilitas 0.005 dibawah 0.005 , maka dapat disimpulkan ada pengaruh yang signifikan dari fasilitas lainnya terhadap keputusan berkunjung. Untuk mengetahui besarnya pengaruh langsung dan tidak langsung physical evidence yang terdiri dari fasilitas eksterior $\left(\mathrm{X}_{1}\right)$, fasilitas interior $\left(\mathrm{X}_{2}\right)$ dan other tangibles $\left(\mathrm{X}_{3}\right)$ terhadap keputusan berkunjung (Y) adalah sebagai berikut:

a. Besar Pengaruh Sub Variabel Fasilitas Ekterior Terhadap Keputusan Berkunjung

1. Pengaruh langsung $X_{1}$ terhadap $Y$ adalah $(0,254)(0,254)=0,0645$

2. Pengaruh tidak langsung $X_{1}$ terhadap $\mathrm{Y}$

- Melalui $X_{2}=(0,254)(0,272)$

$(0,241)=0,0167$

- $\quad$ Melalui $\mathrm{X}_{3}=(0,254)(0,173)$

$(0,324)=0,0142$

Total pengaruh tidak langsung $=0,0309$

Total pengaruh langsung dan tidak langsung

$\mathrm{X}_{1}$ terhadap $\mathrm{Y}=0,095$

b. Besar Pengaruh Fasilitas Interior

Terhadap Keputusan Berkunjung

TABEL 4.27

HASIL PENGUJIAN KOEFISIEN JALUR, PENGARUH LANGSUNG DAN TIDAK LANGSUNG PHYSICAL EVIDENCE TERHADAP KEPUTUSAN BERKUNJUNG

\begin{tabular}{|c|c|c|c|c|c|}
\hline \multirow{2}{*}{$\begin{array}{c}\text { Sub } \\
\text { Variabel }\end{array}$} & \multirow{2}{*}{$\begin{array}{c}\text { Pengaruh Langsung } \\
\text { Terhadap Y }\end{array}$} & \multicolumn{3}{|c|}{$\begin{array}{c}\text { Pengaruh Tidak Langsung } \\
\text { Melalui }\end{array}$} & \multirow{2}{*}{$R^{2} Y_{x 1} \ldots \ldots Y_{x 3}$} \\
\hline & & $\mathrm{X}_{1}$ & $\mathrm{X}_{2}$ & $\mathrm{X}_{3}$ & \\
\hline $\mathrm{X}_{1}$ & 0,0645 & 1 & 0,0167 & 0,0142 & 0,095 \\
\hline $\mathrm{X}_{2}$ & 0,0581 & 0,0167 & 1 & 0,0198 & 0,095 \\
\hline $\mathrm{X}_{3}$ & 0,1050 & 0,0142 & 0,0198 & 1 & 0,139 \\
\hline \multicolumn{5}{|c|}{ Pengaruh Secara Keseluruhan } & $\mathbf{0 , 3 2 9 0}$ \\
\hline
\end{tabular}

Sumber: Pengolahan Data 2012
1. Pengaruh langsung $\mathrm{X}_{2}$ terhadap Yadalah $(0,241)(0,241)=0,0581$

2. Pengaruh tidak langsung $\mathrm{X}_{2}$ terhadap Y

- Melalui $\mathrm{X}_{1}=(0,241)(0,272)$ $(0,254)=0,0167$

- Melalui $\mathrm{X}_{3}=(0,241)(0,254)$ $(0,324)=0,0198$

Total pengaruh tidak langsung $=0,0365$

Total pengaruh langsung dan tidak langsung $\mathrm{X}_{2}$ terhadap $\mathrm{Y}=0,095$

c. Besar Pengaruh Fasilitas Lainnya Terhadap Keputusan Berkunjung

1. Pengaruh langsung $X_{3}$ terhadap Yadalah $(0,324)(0,324)=0,1050$

2. Pengaruh tidak langsung $\mathrm{X}_{3}$ terhadap Y

- $\quad$ Melalui $\mathrm{X}_{1}=(0,324) \quad(0,173)$ $(0,254)=0,0142$

- Melalui $\mathrm{X}_{2}=(0,324)(0,254)$ $(0,41)=0.0198$

Total pengaruh tidak langsung $=0,0341$

Total pengaruh langsung dan tidak langsung $\mathrm{X}_{3}$ terhadap $\mathrm{Y}=0,139$

Untuk lebih jelasnya mengenai besar pengaruh physical evidence yang terdiri dari fasilitas eksterior, fasilitas interior dan other tangibles terhadap keputusan berkunjung dapat dilihat pada tabel berikut : 
Berdasarkan hasil pengujian koefisien jalur, pengaruh langsung dan tidak langsung physical evidence terhadap keputusan berkunjung pada objek wisata Pemandian Air Panas Ciwalini. Pengaruh fasilitas lainnya berpengaruh langsung terhadap keputusan berkunjung dengan nilai paling tinggi sebesar $0.1050(10,50 \%)$, pengaruh tidak langsung melalui fasilitas eksterior sebesar 0.0142 atau $1,42 \%$ dan melalui fasilitas interior sebesar 0.0198 atau $1,98 \%$.

Setelah koefisien jalur dihitung selanjutnya dapat ditentukan besarnya pengaruh secara simultan sub variable physical evidenceyang terdiri dari fasilitas eksterior $\left(\mathrm{X}_{1}\right)$, fasilitas interior $\left(\mathrm{X}_{2}\right)$ dan other tangibles $\left(\mathrm{X}_{3}\right)$ terhadap keputusan berkunjung $(\mathrm{Y})$ melalui koefisien determinasi. Nilai koefisien determinasi diperoleh dari hasil pengolahan data melalui SPSS versi 19.0 dan hasilnya adalah sebagai berikut :

TABEL 4.28 MODEL SUMMARY Model Summary

\begin{tabular}{|l|l|r|r|r|}
\hline Model & R & R Square & \multicolumn{1}{c|}{$\begin{array}{c}\text { Adjusted R } \\
\text { Square }\end{array}$} & $\begin{array}{c}\text { Std. Error of } \\
\text { the Estimate }\end{array}$ \\
\hline 1 & $.574^{\mathrm{a}}$ & .329 & .309 & 4.111170 \\
\hline
\end{tabular}

a. Predictors: (Constant), $\times 3, \times 1, \times 2$

Nilai koefisien determinasi dapat diinterpretasikan sebagai besarnya pengaruh variable independen terhadap variabel dependen. Merujuk pada model summary didapat nilai koefisien determinasi sebesar 0,329 yang berarti besarnya pengaruh sub variabel physical evidence yang terdiri dari fasilitas eksterior $\left(\mathrm{X}_{1}\right)$, fasilitas interior $\left(\mathrm{X}_{2}\right)$ dan other tangibles $\left(\mathrm{X}_{3}\right)$ terhadap keputusan berkunjung (Y) sebesar 32,9\%. Hasil tersebut menunjukkan besarnya pengaruh langsung dan tidak langsung dari seluruh sub variabel physical evidence yang terdiri dari fasilitas eksterior $\left(\mathrm{X}_{1}\right)$, fasilitas interior $\left(\mathrm{X}_{2}\right)$ dan other tangibles $\left(\mathrm{X}_{3}\right)$ terhadap keputusan berkunjung.

\subsection{Impikasi Hasil Temuan}

1. Berdasarkan hasil temuan penelitian penulis memperkuat konsep physical evidence dari Zeithaml, Bitner and Gremler (2013: 278) yang menyebutkan bahwa karakteristik yang terdapat dalam physical evidence seperti fasilitas eksterior, fasilitas interior dan other tangibles tidak hanya diterapkan pada tempat pelayanan jasa, seperti hotel \& restoran, bank dan lainnya tetapi juga dapat diterapkan pada destinasi wisata alam.

2. Berdasarkan hasil temuan penelitian penulis memperkuat konsep keputusan berkunjung merupakan modifikasi dari konsep keputusan pembelian dari Kotler \& Keller (2012:161) yang memiliki dimensi, yaitu : pemilihan produk, pemilihan merek, pemilihan penyalur, jumlah pembelian, penentuan waktu pembelian dan pemilihan metode pembayaran.

3. Dimensi-dimensi physical evidence yang terdiri atas fasilitas eksterior, fasilitas interior dan other tangibles memiliki pengaruh yang signifikan terhadap keputusan berkunjung pada Pemandian Air Panas Ciwalini. Hasil ini mendukung premis-premis yang diungkapkan oleh Zeithaml, Bitner and Gremler (2012) ; Van Der Merwe (2006) dan Ratih Hurriyati (2008).

4. Penerapan physical evidence dalam meningkatkan keputusan berkunjung yang meliputi fasilitas eksterior, fasilitas interior dan other tangibles (seperti ruang ganti, kelengkapan pakaian karyawan dan brisur) dapat dinyatakan bahwa dimensi fasilitas lainnya merupakan faktor yang paling dominan dalam meningkatkan keputusan wisatawan untuk berkunjung ke Pemandian Air Panas Ciwalini.

5. Indikator pembentuk keputusan berkunjung yang paling tinggi kontribusinya adalah pemilihan produk wisata. Hal ini disebabkan karena adanya keunggulan komparatif dan daya tarik yang dimiliki oleh Pemandian Air Panas Ciwalini dibandingkan dengan tempat wisata alam yang sejenis.

6. Hasil penelitian yang mengukuhkan teori sebelumnya dan memodifikasi teori yang ada menjadi suatu penelitian yang memberikan pengaruh cukup besar pada keputusan berkunjung dan memperjelas bahwa peran physical evidence sebagai alternatif strategi dalam upaya meningkatan keputusan berkunjung dari wisatawan ke objek 
wisata alam Pemandian Air Panas Ciwalini

Berdasarkan temuan-temuan tersebut, maka diyakini hasil penelitian penulis mampu memberikan sumbangan ilmiah bagi pengembangan ilmu manajemen pemasaran, khususnya pemasaran jasa khususnya menyangkut aspek physical evidence dan juga sebagai masukan yang konstruktif dan inspiratif bagi pengelola Pemandian Air Panas Ciwalini untuk pengembangan destinasi wisata alam tersebut di masa yang akan datang.

\section{KESIMPULAN DAN REKOMENDASI}

\subsection{Kesimpulan}

Berdasarkan kajian teori, hasil penelitian, dan pengujian path analysis yang dilaksanakan mengenai analisis Physical Evidence terhadap keputusan berkunjung pada Pemandian Air Panas Ciwalini dapat disimpulkan sebagai berikut:

1. Gambaran mengenai physical evidence pada pemandian air panas Ciwalini mendapat penilaian yang tinggi dari pengunjung. Penilaian tertinggi diperoleh oleh fasilitas lainnya sedangkan penilaian terendah diperoleh oleh fasilitas interior seperti dijelaskan di bawah ini:

a) Secara keseluruhan physical evidence pada pemandian air panas Ciwalini sudah tinggi terutama fasilitas lainnya seperti ruang ganti, kelengkapan pakaian karyawan dan brosur, dikarenakan wisatawan yang datang berkunjung merasakan adanya manfaat dari konsistensi pelayanan yang diberikan. Manfaat yang sangat terasa adalah identitas karyawan yang jelas ditunjukkan melalui kartu nama, sehingga memudahkan bagi pengunjung jika membutuhkan bantuan selama berada di tempat tersebut. Mayoritas pengunjung juga menilai pakaian kerja yang dikenakan karyawan menarik, sopan, cocok, rapih dan bersih. Penyampaian informasi melalui brosur yang cukup detail juga memudahkan pengunjung mengetahui kelengkapan dan daya tarik dari pemandian air panas Ciwalini. b) Fasilitas interior mendapatkan penilaian terendah dari pengunjung, hal ini disebabkan karena pengunjung merasa kurang nyaman dengan tata letak kolam renang yang berdekatan antara kolam renang untuk anak dan dewasa masih belum begitu baik, kolam renang dewasa yang memiliki kedalaman 2 meter berbatasan langsung dengan kolam renang anak, sehingga dapat menimbulkan risiko kecelakan bagi anak-anak. Ketersediaan dan kelayakan alat pendukung wisata seperti baju renang, pelampung dan perahu karet untuk anak-anak masih dirasakan sangat terbatas pengunjung.

2. Gambaran mengenai tingkat keputusan berkunjung pada Pemandian Air Panas Ciwalini mendapat penilaian yang tinggi. Penilaian tertinggi diantara variabel dimensi keputusan berkunjung yaitu pemilihan produk. Hal ini disebabkan karena Pemandian Air Panas Ciwalini memiliki sumber air panas yang jernih dan bersih serta ditunjang dengan lokasinya tidak berada di pinggir jalan raya menjadikan keunggulan tersendiri bagi objek wisata tersebut. Sementara penilaian penentuan waktu kunjungan terutama kunjungan pada pada hari-hari kerja biasa (weekdays), hal ini disebabkan karena Senin sampai dengan Jum'at yang merupakan hari-hari sibuk kerja dan sekolah sehingga banyak wisatawan yang tidak datang ketempat tersebut.

3. Secara keseluruhan physical evidence yang terdiri dari atas sub variabel fasilitas eksterior, fasilitas interior dan other tangibles memberikan pengaruh terhadap keputusan berkunjung pada Pemandian Air Panas Ciwalini. Untuk fasilitas lainnya memberikan pengaruh paling tinggi terhadap keputusan berkunjung. Sedangkan yang memiliki pengaruh terendah adalah fasilitas eksterior.

\subsection{Rekomendasi}

Konsep physical evidence merupakan aspek yang sangat penting dalam pemasaran jasa termasuk jasa wisata. Oleh karena itu, penulis mencoba memberikan rekomendasi seperti hal-hal berikut:

1. Berdasarkan hasil penilaian responden terhadap physical evidence Pemandian 
Air Panas Ciwalini, tata letak kolam renang mendapat penilaian yang masih rendah dari pengunjung. Oleh karena itu pengelola sebaiknya menambahkan payung tenda diantara kolam renang dewasa dan anak-anak yang dapat dgunakan pengunjung untuk beristirahat dan mengawasi anakanaknya bermain di kolam rennag. Selain itu pula pengelola menyediakan alat-alat renang seperti pelampung, perahu karet dan rompi renang untuk disewakan kepada pengunjung atau pengelola dapat bekerjasama dengan pedagang yang ada disekitar objek wisata alam tersebut. Tingkat keamanan dan kenyamanan pengunjung yang kurang diperhatikan pengelola tentunya tidak menutup kemungkinan akan menurunkan keinginan pengunjung untuk kembali datang.

2. Secara keseluruhan physical evidence dalam meningkatkan keputusan berkunjung yang meliputi fasilitas eksterior, fasilitas interior dan fasilitas lain sudah dilakukan dengan baik dan terbukti mampu mempengaruhi keputusan berkunjung, namun hal terpenting yang harus diperhatikan oleh pengelola daya adalah mengenai fasilitas interior, karena merupakan faktor yang paling tinggi dalam meningkatkan keputusan berkunjung dengan mengatur laya out kolam renang baik untuk dewasa maupun anak dan memperbaiki lampu-lampu yang tidak berfungsi.

3. Keterbatasan dalam penelitian ini yaitu peneliti hanya melakukan penelitian dengan survei terhadap pengunjung di Pemandian Air Panas Ciwalini. Rekomendasi untuk peneliti berikutnya diharapkan dapat meneliti keputusan berkunjung tidak hanya terbatas pada satu tempat saja, tetapi tetapi tempat pemandian air panas yang ada di wilayah Bandung Selatan mengetahui kompetensi wisata alam yang unggul di wilayah tersebut.

\section{Daftar Pustaka}

Aaker A., David, Kumar, V \& Day, George S. Day. 2009. Marketing Research. $8^{\text {th }}$ Edition. John Wiley \& Sons Inc.
Anggraeni (2007) Bauran Pemasaran dalam Kaitannya dengan memilih jasa transportasi kereta api di Yogyakarta.

Briggs Susan, 2009. Marketing for the Tourism and Leisure, Sydney, Australia.

Buchari, Alma, 2008. Manajemen Pemasaran dan Pemasaran Jasa. Alfabeta,Bandung.

Dinas Pariwisata dan Kebudayaan Kabupaten Bandung. 2012. Data dan Informasi Pariwisata dan Kebudayaan Kabupaten Bandung. Bandung.

Dinas Kebudayaan dan Pariwisata Provinsi Jawa Barat. 2012. Data dan Informasi Kebudayaan dan Pariwisata Provinsi Jawa Barat. Bandung.

Fandy Tjiptono Gregorius Chandra dan Dedi Adriana, 2008. Pemasaran Strategik. Yogyakarta.

Harun Al Rasyid. 2000. Teknik Penarikan Sampel dan Penyusunan Skala. Universitas Padjadjaran, Bandung.

Hendri Sukotjo dan Sumanto Radix A. (2010) Analisa Marketing Mix-7P (Produk, Price, Promotion, Place, Partisipant, Process dan Physical Evidence) terhadap Keputusan Pembelian Produk Klinik Kecantikan Teta di Surabaya.

Henry Purnomo (2011) Pengaruh Faktor Individual Wisatawan dan Kinerja Bauran Pemasaran terhadap Nilai Jasa Pariwisata Alam.

Husein, Umar. 2010. Riset Pemasaran dan Perilaku Konsumen. Jakarta: Rajawali Pers.

I Gde Pitana dan I Ketut Surya Diatra, 2009, Pengantar Ilmu Pariwisata, Penerbit Andi Yogyakarta

Joko Samboro, et al (2010) Pengaruh People, Process dan Physical Evidence terhadap loyalitas keputusan mahasiswa memilih politeknik negeri Malang melalui keputusan pembelian.

Kawung (2006) Analisis pertimbangan faktor bauran pemasaran $7 \mathrm{p}$ yang berpengaruh terhadap pilihan mahasiswa Politeknik Menado.

Kotler and Amstrong. 2012. Principles of Marketing $14^{\text {th }}$ ed. Pearson Hall. New Jersey.

Kotller, Philip dan Keller, Kevin Lane, 2012. Marketing Management $14 \mathrm{e}^{\text {th }}$ edition. New Jersey: Prentice Hall 
Lovelock, Christopher and Lauran Wirtz. www.bps.com 2011. Service Marketing $7^{\text {th }}$ ed. Pearson Hall. New Jersey.

Michele Caroline Van Der Merwe (2006) Marketing Communication Methods Used By Tour Operators In Gauteng, pp. 67-68.

Nyoman S. Pendit, 2006. Ilmu Pariwisata Sebuah Pengantar Perdana. Edisi Terbaru. Jakarta: PT PradnyaParamita.

Oka A.Yoety, 2008 Pemasaran Pariwisata, PT Pradnya Paramitha, Jakarta.

Pasal 7 Peraturan Pemerintah Republik Indonesia No. 36 tahun 2010

Puskopkar PTPN VIII Kabupaten Bandung. . Data dan Informasi Pemandian Air Panas Ciwalini Kabupaten Bandung. Bandung.

Rambat Lupiyoadi dan Hamdani, 2008, Manajemen Pemasaran Jasa: Teori dan Pratek. Jakarta: PT Salemba Empat.

Ratih Hurriyati, 2008. Bauran Pemasaran dan Loyalitas Konsumen, Alfabeta, Bandung.

Richardson. I John. dan Martin, Flucker, 2004, Understanding and Managing Tourism. Australia: Person Hospitality Press.

Schiffman, Leon.G. dan Kanuk, Leslie, 2008. Consumer Behavior. Prentice

Hall InternasionalInc.

Spillane, James Joseph S.Y, 2009. Ekonomi Pariwisata: Sejarah dan Prospeknya. Kanisius, Yogyakarta.

Sugiyono. 2010. Metode Penelitian Bisnis. Bandung: Alfabeta . 2012. Metodologi Penelitian: Alfabeta

Suharsimi Arikunto, (2009), Prosedur Penelitian Suatu Pendekatan Praktis, Yogyakarta: Bina Aksara.

Ulber Silalahi, 2009. Metode Penelitian Sosial, PT Refika Aditama, Bandung.

Vellas Francois, Becherel Lionel, 2008. The international marketing of travel and tourism: a strategic approach, St. Martin Press

Yazid. 2008. Pemasaran Jasa dan Konsep Implementasi. Ekonisia FE VIII. Yogyakarta.

Zeithaml, V.A., M.J. Bitner. 2013. Service Marketing: Integrating Customer Focus Across the Firm $6^{\text {th }} \mathrm{ed}$. McGraw-Hill. Boston.

\section{Internet:}

